\title{
Reflections from Peter's First Graduate Student
}

\author{
Rita Brickman Effros
}

Keywords: personal reflection, graduate school, mentor

\section{Peter's Arrival at Penn}

$\mathbf{I}$ N 1975, I enrolled in the University of Pennsylvania Graduate Program in Immunology. After more than 10 years_-graduating college and professional school, working as a physical therapist, marrying, living in Paris for a year, and beginning to raise a family-I was finally ready to resume my education.

Once at Penn, I completed two of the three required laboratory rotations, but was beginning to doubt that I would ever find a suitable laboratory "home." By chance, someone mentioned that there was a new faculty member, Peter Doherty, recently recruited from Canberra University in Australia, who would certainly be looking for graduate students. As it happened, Peter was giving a seminar the next day, and I learned about a new discovery he had just made regarding something called "MHC restriction." I approached him after the seminar, and he agreed to have me do a rotation in his laboratory. He indicated that my project would be a continuation of his lymphocytic choriomeningitis (LCMV) work. He also happened to mention that in his newly remodeled laboratory, the autoclaves were not yet operational, so we would be using the old-fashioned boiling method of sterilization.

I was a bit concerned with this proposal, since I had two small children at home, and LCMV sounded like a nasty virus. I somehow worked up the nerve to ask Peter if he had any other project I could work on. Those were the days when the mechanism of recognition by the $\mathrm{T}$ cell receptor (TCR) had not yet been fully elucidated. Together with Rolf Zinkernagel, a Swiss physician who had recently arrived in Canberra, Peter had recently shown that LCMV-specific cytotoxic $\mathrm{T}$ lymphocytes (CTL) are targeted to particular major histocompatibility complex (MHC) Class I glycoproteins with exquisite precision, but the details of viral recognition were still unclear. In response to my request, Peter came up with the idea that influenza might be a useful model to address the fine specificity of TCR viral recogni- tion, since the A strain viruses would offer the possibility of investigating a closely related, defined panel of pathogens.

Luckily, Walter Gerhard, trained in influenza biology at the Basel Institute for Immunology, had recently joined the Wistar Institute, where Peter's laboratory was located, and so, I received expert instruction on growing various strains of recombinant influenza that would be necessary for my project. Peter then left me on my own to set up the flu CTL assay-showing confidence that someone who essentially had no laboratory experience since college could accomplish this. Fast forward several months, and I actually began to accumulate some data. The work eventually showed that CD8 T cells are highly cross-reactive, in contrast to the fine specificity shown by antibody responses directed at the hemagglutinin $(\mathrm{H})$ and neuraminidase $(\mathrm{N})$ glycoproteins $(12,13)$. These results were counterintuitive, and Peter insisted that I repeat the experiments multiple times until we were confident that $\mathrm{T}$ cells from mice primed, for example, with influenza PR8 (H1N1) could kill targets infected with influenza $\mathrm{HK}$ (H3N2).

Together with the MHC restriction findings, these influenza results suggested that the still-elusive TCR was seeing something quite distinct from what was recognized by $\mathrm{B}$ cells. Indeed, it turned out that influenza-specific CTL are highly cross-reactive across all the A strain influenza viruses, in stark contrast to the fine specificity that would be expected from analysis of humoral responses to the hemagglutinin and neuraminidase antigens. Further analysis of this unexpected observation eventually led to my $\mathrm{PhD}$ degree-which, along with Peter's second graduate student, Jack Bennink, was completed in 3 years $(2,3,10,11,17)$.

Whereas the novel insights into TCR recognition that emerged from my thesis work were clearly important, there is no doubt in my mind that the most critical part of my training was not $\mathrm{T}$ cell viral immunology, but rather, the revelation that doing science can be fun. Those were the days when Peter still had time to work at the bench, and so, on a daily basis, I was exposed to his incisive scientific

Department of Pathology and Laboratory Medicine, David Geffen School of Medicine at UCLA, Molecular Biology Institute, UCLA AIDS Institute, Los Angeles, California.

(C) Rita Brickman Effros et al., 2020; Published by Mary Ann Liebert, Inc. This Open Access article is distributed under the terms of the Creative Commons Attribution Noncommercial License (http://creativecommons.org/licenses/by-nc/4.0/) which permits any noncommercial use, distribution, and reproduction in any medium, provided the original author(s) and the source are cited. 
reasoning, optimistic attitude, and, of course, his great sense of humor. While most of my classmates seemed to be stressed out much of the time, my own experience in graduate school was actually quite positive and totally exhilarating.

In return for the outstanding mentorship that Peter provided, I am pleased that my request to avoid LCMV led to Peter's total transition to the flu model, which has been the continuous focus of his research ever since. I even recall that he once mentioned to me that "the flu saved my life," which may have been a bit of a hyperbole, but it made me feel good, nonetheless.

\section{After Peter}

Based on my experience in Peter's laboratory, I was hooked on viral immunology, with a specific focus on CD8 T cells. I joined a group at UCLA, headed by Roy Walford, who, in 1965, had proposed "The immunological theory of aging," an article that has proven to be quite prescient (32). Indeed, it is becoming increasingly clear that most of the chronic diseases of aging involve inflammatory components. Roy's laboratory had recently shown that mice subjected to a reduced calorie diet seemed to age more slowly. For example, the altered lens protein associated with cataracts did not accumulate with age in these mice. Using my own experience with influenza in the life span-extending model of caloric restriction, we showed that the antiviral CTL activity was also enhanced in these mice.

Being immersed in the field of aging helped me to become aware of the major discipline of gerontological research known as cellular/replicative senescence. This area had originally emerged from the work of Leonard Hayflick in the 1960s, who, coincidentally, had also spent his early career at the Wistar Institute. Most of the research on cellular senescence was focused on the human fibroblast model. Interestingly, at about the same time, there were numerous reports from immunologists using IL-2, then called "T cell growth factor," to establish long-term cultures of human T cells. Surprisingly, some of the articles described the cell cultures as "immortal," suggesting that $\mathrm{T}$ cells might be an exception to the well-documented "Hayflick Limit," a feature thus far confirmed on all human cells grown in tissue culture (22). As it happens, many of these putatively immortal $\mathrm{T}$ cell cultures were actually frozen for periods of time and then thawed briefly for specific assays. So, they were "immortal" in terms of the research life span of the investigator, but not necessarily truly immortal, in the same sense as tumor cells are.

Based on my extensive work on CD8 T cells in Peter's laboratory, I decided to focus on this subset to systematically address the question of whether immune cells were subject to the same senescence program as all other human somatic cells. We established long-term cultures of human CD8 T cells, using either tumors or virally pulsed autologous cells as "stimulators." Our work showed that human T cells had the same intrinsic program as fibroblasts and all other human somatic cells, namely, that they undergo cellular senescence in culture after a finite number of cell divisions. Along with the irreversible cell cycle arrest, senescent CD8 T cells have shortened telomeres, inability to upregulate telomerase, and are resistant to apoptosis. They also show increased secretion of proinflammatory cytokines and permanent suppression of CD28 gene expression $(4,6,7,15,22-31)$.
Our in vitro work was confirmed in clinical studies. Cells with an identical phenotype accumulate in elderly persons, and in an accelerated manner in younger persons chronically infected with HIV $(8,9)$. It seems that persistent infections can drive human CD8 $\mathrm{T}$ cells to the end stage of cellular senescence, and due to their resistance to apoptosis, these cells accumulate over time. In the case of aging, it is now well established that the driving force is chronic infection with cytomegalovirus (CMV). Indeed, in some older individuals, CMV-specific CD8 T cells constitute a large proportion of the entire $T$ cell repertoire, resulting in a constriction of the remaining $\mathrm{T}$ cell repertoire. Looking back on my scientific career, it is clear that my focus on various facets of CD8 $\mathrm{T}$ cell biology was molded by my early training in Peter's laboratory.

\section{Coming Full Circle}

In addition to my laboratory research, my entrée into the field of gerontology has also involved didactic activities. As part of an interdisciplinary team, I helped develop a yearlong Honors-level course for college freshman, entitled, Frontiers of Human Aging: Biomedical, Social and Policy Perspectives - now in its 20th year. One of the major topics covered in this course relates to challenges involved in influenza vaccination of the elderly population (1). We discuss the biology of the virus itself, the tedious process by which flu vaccines are currently prepared, social issues related to vaccines in general, and vaccination strategies to compensate for the aging immune system $(5,14,16)$. In a sense, therefore, I have come full circle-ending my career with a topic with which it first began in Peter's laboratory.

\section{Concluding Remarks}

I have enjoyed seeing Peter over the years at immunology meetings, and was sorry that UCLA was not successful many years ago in recruiting him to direct a new Vaccine Program. Australia was a much better fit, and I know he has flourished in Melbourne. Most recently, when I was elected President of the Gerontological Society of America, this Nobel Laureate wrote to me, "I have bragging rights." That was the essence of Peter-a truly modest man, a brilliant scientist, a superb mentor, and an extraordinary human being. I consider myself extremely fortunate to have been trained in his laboratory, and I will always be proud to have had the honor of being his first graduate student.

\section{Author Disclosure Statement}

No competing financial interests exist.

\section{References}

1. Aspinal R, Del Giudice G, Effros RB, GrubeckLoebenstein B, and Sambhara, S. Challenges for vaccination in the elderly. Immun Ageing 2007;4:9-18.

2. Bennink J, Effros RB, and Doherty PC. Influenza pneumonia: early appearance of cross-reactive $\mathrm{T}$ cells in lungs of mice primed with heterologous type A virus. Immunology 1978;35:503-508.

3. Biddison WE, Snodgrass HR, Bennink J, Effros RB, and Doherty PC. Induction of virus-specific modification recognized cytotoxic T cells is not altered by prior substitution of target cells with TNP. J Exp Med 1977;146:617-622. 
4. Bodnar AG, Kim NW, Effros RB, and Chiu C-P. Mechanism of telomerase induction during $\mathrm{T}$ cell activation Exp. Cell Res 1996;228:58-64.

5. Chen WH, Kozlocsky BF, Effros RB, et al. Vaccination in the Elderly: an immunological perspective. Trends Immunol 2009;7:351-359.

6. Choi J, Fauce SR, and Effros RB. Reduced telomerase activity in human T lymphocytes exposed to cortisol. Brain Behav Immun 2008;22:600-605.

7. Chou JP, Ramirez CM, Ryba DM, Koduri MP, Effros RB. Prostaglandin E2 promotes features of replicative senescence in chronically activated human CD8+ T cells. PLoS One 2014;9:e99432.

8. Chou JP, Ramirez CM, Wu JE, and Effros RB. Accelerated aging in HIV/AIDS: novel biomarkers of senescent human CD8+ T cells. PLoS One 2013;8:e64702.

9. Dagarag M, Evazyan T, Rao N, and Effros RB. Genetic manipulation of telomerase in HIV-specific CD8+ T cells: enhanced anti-viral functions accompany the increased proliferative potential \& telomere length stabilization. J Immunol 2004;173:6303-6311.

10. Doherty PC, Bennink J, Effros RB, and Biddison WE. Possible implications of the influenza model for $\mathrm{T}$ cell recognition. In: Fox R, Sercarz E, Herzenberg L, eds. Regulatory Genetics of the Immune System, ICN-UCLA Symposia on Molecular \& Cellular Biology, vol. VI. New York: Academic Press, 1977:599-606.

11. Doherty PC, Bennink JR, Effros RB, and Frankel ME. The dual specificity of virus-immune $T$ cells: Functional indications that virus and $\mathrm{H}-2$ molecules may associate on cell membrane. In: Reisfeld R, Ferrone S, eds. Current Trends in Histocompatibility. New York: Plenum Press, 1980.

12. Doherty PC, Effros RB, and Bennink J. Cell-mediated immunity in virus infections: Influenza virus and the problem of non-self discrimination. In: Pollard M, ed. Perspectives in Virology, vol. 10. New York: Raven Press, 1978:73-88.

13. Doherty PC, Effros RB, and Bennink J. Heterogeneity of the cytotoxic $\mathrm{T}$ cell response following immunization with influenza viruses. Proc Natl Acad Sci USA 1977;74:1209_ 1213.

14. Effros RB. Problems \& solutions to development of vaccines for aged humans. Immunol Allergy Clin North Am 2003;23:41-55.

15. Effros RB. Replicative senescence of CD8 T cells: potential effectos on cancer immune surveillance $\&$ immunotherapy. Cancer Immunol Immunother 2004;53:925-933.

16. Effros RB. The canary in the coal mine: telomeres and human healthspan. J Gerontol Biol Sci Med Sci 2009;64: 511-515.

17. Effros RB, Allsopp R, Chiu C-P, et al. Shortened telomeres in the expanded $\mathrm{CD} 28^{-} \mathrm{CD}^{+}$subset in HIV disease implicate replicative senescence in HIV disease pathogenesis. AIDS 1996;10:F17-F22.

18. Effros RB, Bennink J, and Doherty PC. Characteristics of secondary cytotoxic $\mathrm{T}$ cell responses in mice infected with influenza A viruses. Cell Immunol 1978;36:345-353.
19. Effros RB, Boucher N, Porter V, et al. Decline in CD28+ T cells in centenarians and in longterm $\mathrm{T}$ cell cultures: a possible cause for both in vivo and in vitro senescence. Exp Gerontol 1994;29:601-609.

20. Effros RB, Doherty PC, Gerhard W, and Bennink J. Generation of both cross-reactive and virus-specific $\mathrm{T}$ cell populations following immunization with serologically distinct influenza A viruses. J Exp Med 1977;145:557-568.

21. Effros RB, Frankel M, Gerhard W, and Doherty PC. Inhibition of influenza-immune $\mathrm{T}$ cell effector function by virus-specific hybridoma antibody. J Immunol 1979;123: 1343-1346.

22. Effros RB, and Walford RL. T Cell cultures and the Hayflick limit. Human Immunol 1984;9:49-65.

23. Effros RB, Zhu X, and Walford RL. Stress proteins of senescent human T lymphocytes: reduced hsp70 is independent of the proliferative block. J Gerontol 1994;49: B65-B71.

24. Fauce SR, Jamieson BD, Chin A, et al. Telomerase-based pharmacologic enhancement of antiviral function of human $\mathrm{CD}^{+} \mathrm{T}$ lymphocytes. J Immunol 2008;181:7400-7406.

25. Frankel M, Effros RB, Doherty PC, and Gerhard W. A monoclonal antibody to viral glycoprotein blocks virusimmune effector $\mathrm{T}$ cells operating at $\mathrm{H}-2 \mathrm{D}^{\mathrm{d}}$ but not at $\mathrm{H}-$ 2K K $^{\mathrm{d}}$ J Immunol 1979; 123:2438-2440.

26. Parish ST, Wu J, and Effros RB. Modulation of T lymphocyte replicative senescence via $\mathrm{TNF} \alpha$ inhibition: role of caspase-3. J Immunol 2009;182:4237-4243.

27. Parish ST, Wu JE, and Effros RB. Sustained CD28 expression delays multiple features of replicative senescence in human CD8 T cells. J Clin Immunol 2010;30:798-805.

28. Perillo N, Naeim F, Walford RL, and Effros RB. In vitro cellular aging: in T lymphocyte cultures: analysis of DNA content and cell size. Exp Cell Res 1993;107:131.

29. Perillo N, Walford RL, Newman M, and Effros RB. Human $\mathrm{T}$ lymphocytes possess a limited in vitro lifespan. Exp Gerontol 1989;24:177-187.

30. Valenzuela HF, and Effros RB. Divergent telomerase patterns in human CD4 and CD8 T cells following repeated encounters with the same antigenic stimulus. Clin Immunol 1996;105:117-125.

31. Vaziri H, Schachter F, Uchida I, et al. Loss of telomeric DNA during aging of normal and trisomy 21 human lymphocytes. Am J Hum Genet 1993;52:661-667.

32. Walford RL. The Immunologic Theory of Aging. Copenhagen: Munksgaard, 1969.

Address correspondence to: Dr. Rita Brickman Effros

Department of Pathology and Laboratory Medicine David Geffen School of Medicine at UCLA Molecular Biology Institute UCLA AIDS Institute Los Angeles, CA 90095

E-mail: reffros@mednet.ucla.edu 